\title{
A study of the nitrogen stable isotope dynamics of phytoplankton in a simple natural ecosystem
}

\author{
Hideyuki Doi $^{1, *}{ }^{,}$Eisuke Kikuchi ${ }^{2}$, Shuichi Shikano ${ }^{2}$, Shigeto Takagi ${ }^{1}$ \\ ${ }^{1}$ Graduate School of Life Sciences, Tohoku University, Katahira, Aoba-ku, Sendai 980-8577, Japan \\ ${ }^{2}$ Center for Northeast Asian Studies, Tohoku University, Kawauchi, Aoba-ku, Sendai 980-8576, Japan
}

\begin{abstract}
We investigated fluctuations in the nitrogen stable isotope ratio $\left(\delta^{15} \mathrm{~N}\right)$ of Chlamydomonas acidophila (Chlorophyceae) by short-interval sampling during a bloom that occurred from 11 May to 29 July 2001 in Lake Katanuma, Japan. In this lake, C. acidophila uses $\mathrm{NH}_{4}{ }^{+}$as the primary inorganic nitrogenous nutrient, since only trace amounts of other inorganic nitrogenous compounds are present. The $\delta^{15} \mathrm{~N}$ values obtained for $C$. acidophila ranged from -7.8 to $-3.4 \%$ o during the study period. The lowest values occurred during periods characterized by high concentrations of $\mathrm{NH}_{4}^{+}$ $\left(>15 \mu \mathrm{mol} \mathrm{l}^{-1}\right.$ ), and our results showed that $\delta^{15} \mathrm{~N}$ values for $C$. acidophila were negatively correlated with concentrations of $\mathrm{NH}_{4}{ }^{+}$. The results suggest that this nutrient plays a major role in the variation of the $\delta^{15} \mathrm{~N}$ value for this species. The nitrogen isotope fraction factor $(\varepsilon)$ of $C$. acidophila was much lower than that of many $\mathrm{NH}_{4}{ }^{+}$-based primary producers from other eutrophic environments.
\end{abstract}

KEY WORDS: Nitrogen · Stable isotope - Phytoplankton · Isotope fractionation - Inorganic nutrient · Acidic lake $\cdot$ Spring bloom $\cdot$ Lake Katanuma

\section{INTRODUCTION}

Nitrogen stable isotope ratios $\left(\delta^{15} \mathrm{~N}\right)$ have become an important tool for the study of both the sources and the biogeochemical processing of organic matter in aquatic ecosystems (Minagawa \& Wada 1986, Cifuentes et al. 1989, Meyers 1994). Recently, the factors that determine the $\delta^{15} \mathrm{~N}$ value of many phytoplankton species have been studied using pure algal cultures in the laboratory (e.g. Pennock et al. 1996, Waser et al. 1998, 1999). Laboratory culture experiments have shown wide fluctuations in the $\delta^{15} \mathrm{~N}$ values of different algal species and their isotope fractionation factors $(\varepsilon)$, which can be used as indicators of ${ }^{15} \mathrm{~N}$-enrichment and the assimilation of dissolved inorganic nitrogen (DIN) by phytoplankton. Variation in $\delta^{15} \mathrm{~N}$ values has been reported to depend on a range of factors, such as the species of algae and culture conditions (nutrient supply, light intensity, temperature, etc.) (Wada \& Hattori 1978, Wada
1980, Hoch et al. 1992, Waser et al. 1998, 1999). Moreover, the experiments investigating changes in the $\delta^{15} \mathrm{~N}$ values of phytoplankton using laboratory cultures have been conducted only on short time scales (usually hours), since under culture conditions nutrient concentrations decrease and the biomass of phytoplankton increases quickly (Pennock et al. 1996, Waser et al. 1998, 1999).

To date, there have been no detailed studies of the $\delta^{15} \mathrm{~N}$ value dynamics of phytoplankton in natural lakes, and little is known about the factors that determine the $\delta^{15} \mathrm{~N}$ values of phytoplankton in natural systems. There is a clear need to investigate fluctuations in $\delta^{15} \mathrm{~N}$ values of phytoplankton in lakes, with reference to changes in biomass and environmental factors. Such information would be useful for determining the factors that affect variation of $\delta^{15} \mathrm{~N}$ values in nature.

Lake Katanuma is a volcanic, strongly acidic lake (annual average $\mathrm{pH}$ of 2.2). The phytoplankton community in the lake is very simple, with only 1 domi- 
nant species, Chlamydomonas acidophila (Chlorophyceae), which often accumulates at the water surface, producing dark-green scum close to the lakeshore. During these periods, we were able to obtain almost pure samples of $C$. acidophila for use in our experiments. In general, lake phytoplankton communities are composed of many microalgal species, which usually complicates determination of the relationships between the $\delta^{15} \mathrm{~N}$ value of individual phytoplankton species and the prevailing physiological and environmental conditions. As a result, $\delta^{15} \mathrm{~N}$ values have frequently been measured in whole phytoplankton communities (e.g. Pennock et al. 1996). In this study, however, we were able to analyze the relationships between the $\delta^{15} \mathrm{~N}$ value of a single phytoplankton species and the controlling environmental conditions.

In the present study, we investigated changes in the $\delta^{15} \mathrm{~N}$ value and biomass of Chlamydomonas acidophila and DIN concentrations in Lake Katanuma from May to July (during the spring bloom). We also conducted a short-interval sampling experiment from the start to the peak of the bloom, to reveal the short-term fluctuations in the $\delta^{15} \mathrm{~N}$ value of this phytoplankton species under natural conditions.

\section{MATERIALS AND METHODS}

Study area. Lake Katanuma is a volcanic lake in northeastern Japan $\left(38^{\circ} 44^{\prime} \mathrm{N}, 140^{\circ} 43^{\prime} \mathrm{E}\right)$, at an altitude of $306 \mathrm{~m}$ above sea level. It is highly acidic, with annual variation in $\mathrm{pH}$ ranging from 2.0 to 2.4 . The lake has a surface area of $0.14 \mathrm{~km}^{2}$ and a maximum depth of $20 \mathrm{~m}$. It is essentially a closed system, with no inflowing or outflowing streams, and is dimictic, with stratification and circulation periods from April to August and from September to December, respectively. Ice usually covers the lake from January to March. Zooplanktonic and nektonic organisms have not been observed in Lake Katanuma (Doi et al. 2001); therefore, herbivores for phytoplankton do not exist in the lake. Moreover, the dissolved $\mathrm{CO}_{2}$ concentration of the lake water exceeds $0.04 \mathrm{mmol} \mathrm{l}^{-1}$ despite its extremely low $\mathrm{pH}$, since $\mathrm{CO}_{2}$ gas is supplied from fumaroles in the lake bottom. The continuous supply of $\mathrm{CO}_{2}$ gas from these fumaroles might maintain higher $\mathrm{CO}_{2}$ concentrations for phytoplankton photosynthesis in Lake Katanuma (Doi et al. 2003a,b).

Collecting and preparation of samples. Green surface water attributed to the presence of Chlamydomonas acidophila was observed along the lakeshore from 15 May to 29 July 2001. Lake surface water samples were collected for analysis from 11 May to 17 July 2001. The green coloration of the surface water was not observed on 11 May. Water samples were collected where $C$. acidophila had accumulated near the shore of the lake. Triplicate water samples were filtered through Whatman GF/F glass-fiber filters (precombusted at $500^{\circ} \mathrm{C}$ for $2 \mathrm{~h}$ ) to collect phytoplankton. To determine the abundance of $C$. acidophila, chlorophyll a ( $\mathrm{chl} \mathrm{a)} \mathrm{concentrations} \mathrm{of} \mathrm{the} \mathrm{water} \mathrm{sam-}$ ples were measured using a fluorometer (10-AU, Turner Designs), following extraction using triplicate GF/F filters with $\mathrm{N}, \mathrm{N}$-dimethylformamide. The concentrations of inorganic nutrients $\left(\mathrm{NH}_{4}{ }^{+}, \mathrm{NO}_{2}{ }^{-}, \mathrm{NO}_{3}{ }^{-}\right.$, and $\mathrm{PO}_{4}{ }^{3-}$ ) were determined for triplicate samples of filtered lake water collected from the surface near the lakeshore between 11 May and 17 July and from $10 \mathrm{~m}$ depth at the center of the lake on 15 May. The concentration of $\mathrm{NH}_{4}{ }^{+}$was determined according to the method of Scheiner (1976). The concentrations of $\mathrm{NO}_{2}{ }^{-}, \mathrm{NO}_{3}{ }^{-}$, and $\mathrm{PO}_{4}{ }^{3-}$ were measured using the colorimetric analyses described by Strickland \& Parsons (1972), following neutralization of the filtered water samples with sodium hydroxide. The water temperature of the lake was measured using a multiple water quality sensor (U-22, Horiba). Sampling was carried out daily from 15 to $22 \mathrm{May}$, at 2 to 5 d intervals from 25 May to 5 June, and weekly or biweekly from 5 June to 17 July.

To measure $\delta^{15} \mathrm{~N}$ values for $\mathrm{NH}_{4}{ }^{+}$, surface water was collected on 15 May, 19 June, and 17 July from the Chlamydomonas acidophila sampling area. We were able to measure $\delta^{15} \mathrm{~N}$ values for $\mathrm{NH}_{4}{ }^{+}$only for the lake water collected from the surface (near the lakeshore) and at a depth of $10 \mathrm{~m}$ (at the center of the lake) on 15 May, since the $\mathrm{NH}_{4}{ }^{+}$concentrations of the water samples collected on 19 June and 17 July were too low to measure the $\delta^{15} \mathrm{~N}$ values. The $\delta^{15} \mathrm{~N}$ values for $\mathrm{NH}_{4}{ }^{+}$were measured in triplicate samples, using the following method, described by Holmes et al. (1998). The filtered lake water (2 l) was placed in a diffusion bottle, and $100 \mathrm{~g} \mathrm{NaCl}$ was added. Then, a precombusted Whatman GF/D glass filter that had been soaked with $2 \mathrm{~mol} \mathrm{l}^{-1} \mathrm{H}_{2} \mathrm{SO}_{4}$ was placed in the headspace of the diffusion bottle. After adding $6 \mathrm{~g}$ $\mathrm{MgO}$ to the diffusion bottle, the bottle was incubated for $2 \mathrm{wk}$ on a shaker. Moreover, we measured the standard diffusion samples using the lake surface water to correct for the fractionation of samples with refer to Holmes et al. (1998). The $\delta^{15} \mathrm{~N}$ value of the phytoplankton and $\mathrm{NH}_{4}{ }^{+}$on the glass-fiber filter was measured using a mass spectrometer (Delta plus, Finnigan Mat) connected to an elemental analyzer (NA2500, CE Instruments). Results were reported in delta notation as: $\delta^{15} \mathrm{~N}=\left({ }^{15} \mathrm{~N} /{ }^{14} \mathrm{~N}_{\text {sample }} /{ }^{15} \mathrm{~N} /{ }^{14} \mathrm{~N}_{\text {standard }}\right.$ - 1) $\times 1000$ (\%o), where air $N_{2}$ was used as the standard. The analytical error was estimated to be approximately $\pm 0.2 \%$. 


\section{RESULTS}

\section{Concentrations of inorganic nutrients in Lake Katanuma}

The concentrations of $\mathrm{NH}_{4}{ }^{+}$and $\mathrm{PO}_{4}{ }^{3-}$ in Lake Katanuma are shown in Fig. 1A. The concentrations of $\mathrm{NH}_{4}{ }^{+}$between 11 and 20 May ranged from 6.6 to $9.4 \mathrm{\mu mol} \mathrm{l}^{-1}$. The concentrations of $\mathrm{NH}_{4}{ }^{+}$increased to 15 to $20 \mu \mathrm{mol} \mathrm{l}^{-1}$ between 21 and 29 May. This increase was probably because of vertical mixing of water at the lakeshore, since the water collected at a depth of $10 \mathrm{~m}$ in the hypolimnion had high concentrations of $\mathrm{NH}_{4}{ }^{+}$ $\left(25.1 \pm 7.5 \mu \mathrm{mol} \mathrm{l}^{-1}\right.$ on 15 May, mean $\left.\pm 1 \mathrm{SD}, \mathrm{n}=3\right)$. The concentration of $\mathrm{NH}_{4}^{+}$in the lake water then decreased from 29 May to 19 June, and thereafter remained at low concentrations $\left(0.5-4.4 \mu \mathrm{mol} \mathrm{l}^{-1}\right)$, due to consumption by Chlamydomonas acidophila. The concentrations of $\mathrm{NO}_{3}{ }^{-}$and $\mathrm{NO}_{2}{ }^{-}$in Lake Katanuma were below detection limits throughout the study period; thus, $\mathrm{NH}_{4}{ }^{+}$was the only detectable form of inorganic nitrogen in the lake. The concentrations of $\mathrm{PO}_{4}{ }^{3-}$ were $<3 \mu \mathrm{mol} \mathrm{l}{ }^{-1}$ between 11 May and 17 July (except for 19 June, $7.4 \pm 1.0 \mu \mathrm{mol} \mathrm{l}^{-1}$ ). However, there was no evidence that $\mathrm{PO}_{4}{ }^{3-}$ limited the growth of $C$. acidophila, since the mean N/P was $6.9 \pm 4.8$ (mean \pm 1 $\mathrm{SD}$ ) over the study period. These ratios are lower than the Redfield ratio value of 16 , which is used as an indicator of $\mathrm{PO}_{4}{ }^{3-}$ limitation (Redfield 1963, Hecky et al. 1993).

\section{Biomass of Chlamydomonas acidophila}

The concentrations of chl a reflected the biomass of Chlamydomonas acidophila in the lake. Concentrations of chl a were low $\left(0.3 \pm 0.2 \mu \mathrm{g} \mathrm{l}^{-1}\right.$, mean $\pm 1 \mathrm{SD}$, $\mathrm{n}=3$ ) on 11 May, before the spring bloom (Fig. 1B). At the beginning of the bloom, the concentration increased to $154.5 \pm 86.3 \mu \mathrm{g} \mathrm{l}^{-1}$ on $16 \mathrm{May}$, then decreased to $16.5 \pm 1.0 \mathrm{\mu g} \mathrm{l}^{-1}$ on 19 May. Values then

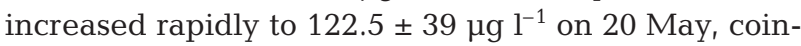
ciding with an increase in $\mathrm{NH}_{4}^{+}$concentration, then decreased to around $200 \mu \mathrm{g} \mathrm{l}^{-1}$ from 22 to 25 May, before increasing and peaking on 29 May at a concentration of $989.9 \mu \mathrm{g} \mathrm{l}^{-1}$. Thereafter, the chl a concentrations gradually decreased to around $250 \mu \mathrm{g} \mathrm{l}^{-1}$. This chl a fluctuation resulted from both growth at the shore site and the vertical and horizontal migration of phytoplankton with water movement.

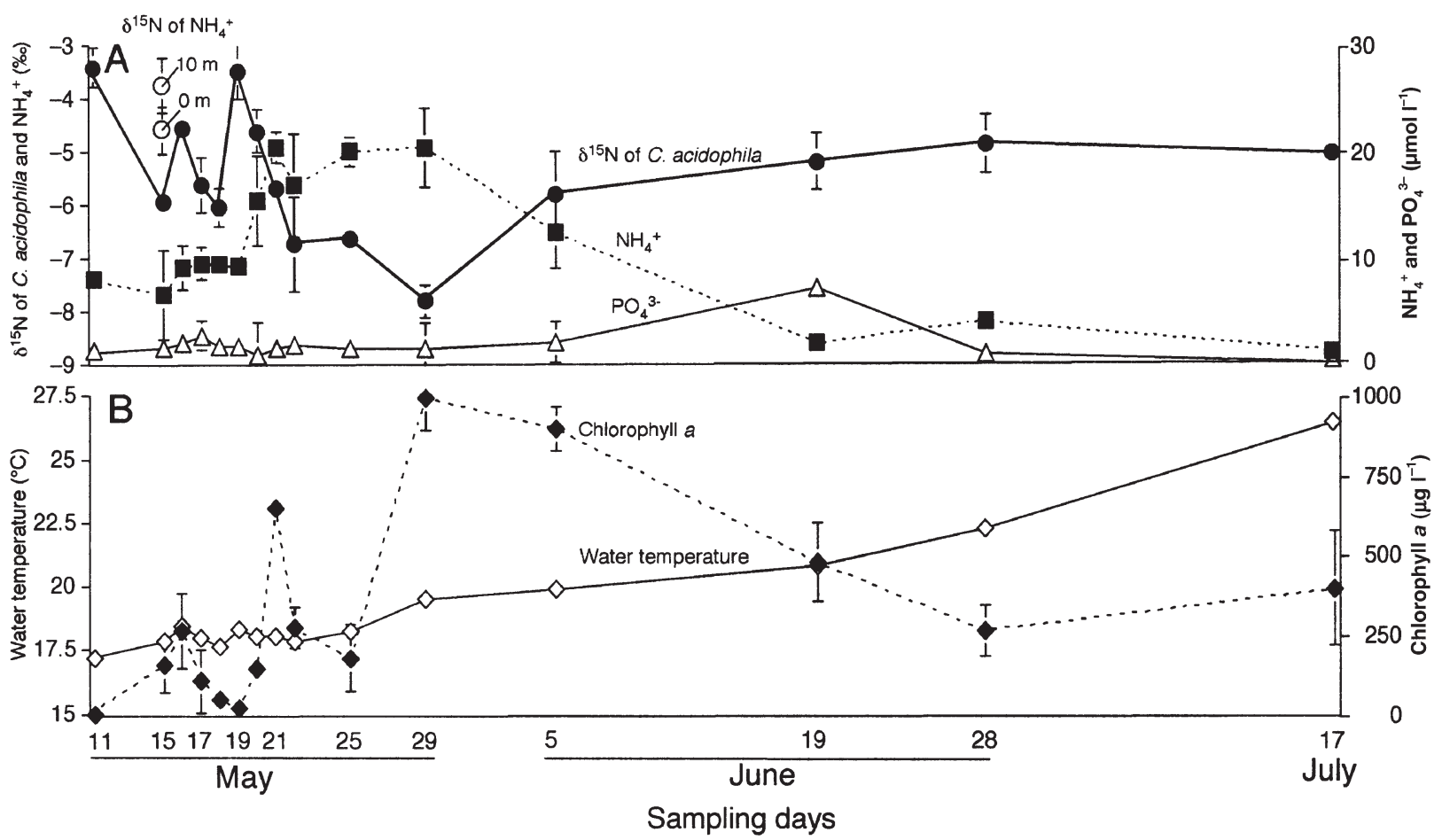

Fig. 1. Chlamydomonas acidophila. (A) $\delta^{15} \mathrm{~N}$ values for C. acidophila, $\mathrm{NH}_{4}{ }^{+}$, and the concentrations of $\mathrm{NH}_{4}{ }^{+}$and $\mathrm{PO}_{4}{ }^{3-}$ in the surface water. $(\bullet, 0) \delta^{15} \mathrm{~N}$ values obtained for $C$. acidophila and $\mathrm{NH}_{4}{ }^{+},(\mathbf{\square}, \Delta)$ concentrations of $\mathrm{NH}_{4}{ }^{+}$and $\mathrm{PO}_{4}{ }^{3-}$, respectively. Left $y$-axis: $\delta^{15} \mathrm{~N}$ values obtained for $C$. acidophila and $\mathrm{NH}_{4}{ }^{+}$; right $y$-axis: concentrations of $\mathrm{NH}_{4}{ }^{+}$and $\mathrm{PO}_{4}{ }^{3-}$. Error bars indicate $\pm 1 \mathrm{SD}$ $(\mathrm{n}=3)$. (B) Concentrations of chl $a$ and water temperature in Lake Katanuma. $(\diamond, \diamond)$ Concentrations of chl $a$ and water temperature, respectively. Left $y$-axis: water temperature; right y-axis: concentrations of chl $a$. Error bars indicate \pm 1 SD $(n=3$ ) 


\section{Water temperature in Lake Katanuma}

Variations in the surface water temperature of Lake Katanuma are shown in Fig. 1B. A seasonal increase in water temperature was observed over the sampling period from 11 May to 17 July (from 17.2 to $26.6^{\circ} \mathrm{C}$ ), although there was a slight decrease in the water temperature in the middle of May. Water temperatures between 15 and 29 May were 17.8 to $19.5^{\circ} \mathrm{C}$, similar to those used in a laboratory study investigating the $\delta^{15} \mathrm{~N}$ values of some phytoplankton species (Pennock et al. 1996, Waser et al. 1998).

\section{Variation in the $\delta^{15} \mathrm{~N}$ value of Chlamydomonas acidophila and $\mathrm{NH}_{4}{ }^{+}$in Lake Katanuma}

The $\delta^{15} \mathrm{~N}$ values obtained for Chlamydomonas acidophila are shown in Fig. 1A. Values varied during the sampling period, ranging from -7.8 to $-3.4 \%$. On 11 May, before the spring bloom, the value was high at $-3.4 \pm 0.4 \%$ o (mean $\pm 1 \mathrm{SD}, \mathrm{n}=3)$, but the low concentration of chl a detected in the sample $\left(0.3 \pm 0.2 \mu \mathrm{g} \mathrm{l}^{-1}\right)$ suggests that the sample might have included some bacterial organic matters. After $11 \mathrm{May}, \delta^{15} \mathrm{~N}$ values were presumed to reflect the presence of $C$. acidophila, since the concentrations of chl a remained high (from 16.5 to $989.9 \mu \mathrm{g} \mathrm{l}^{-1}$ ). The $\delta^{15} \mathrm{~N}$ value of $C$. acidophila fluctuated within the range of -7.8 to $-3.5 \%$ from the start (15 May) to the peak (5 June) of the bloom, and showed high values of $-4.6,-3.5$, and $-4.6 \%$, on 16,19 , and 20 May, respectively. Low values $(-7.8$ to $-6.4 \%$ ) were recorded between 22 and 29 May. Thereafter, from 19 June to 17 July, values tended to be higher, ranging from -5.2 to $-4.8 \%$. The $\delta^{15} \mathrm{~N}$ values of $\mathrm{NH}_{4}{ }^{+}$in lake water collected on 15 May from the surface and at a depth of $10 \mathrm{~m}$ were $-4.9 \pm 0.3$ and $-3.6 \pm 0.5 \%$ o (mean $\pm 1 \mathrm{SD}, \mathrm{n}=3$ ), respectively.

\section{DISCUSSION}

Natural phytoplankton populations usually assimilate $\mathrm{NO}_{3}{ }^{-}$, the most common inorganic nitrogenous compound in most lakes (Wetzel 2001). In Lake Katanuma, however, $\mathrm{NH}_{4}{ }^{+}$is the most common form of nitrogen, and concentrations of $\mathrm{NO}_{3}{ }^{-}$are below the limits of detection. The most likely explanation for this is that nitrification proceeds slowly under acidic conditions $(<\mathrm{pH} 5)$, leading to a build-up of $\mathrm{NH}_{4}{ }^{+}$(Wetzel 2001). Mitamura \& Saijo (1986) suggested that the relative nitrogen assimilation rates of inorganic nitrogenous compounds by phytoplankton are in the following order: ammonium > urea > nitrate. Therefore, the available evidence suggests that the Chlamydomonas acidophila populations in Lake Katanuma use $\mathrm{NH}_{4}{ }^{+}$as the substrate for conversion into proteins.

Very few $\delta^{15} \mathrm{~N}$ values have been obtained for $\mathrm{NH}_{4}{ }^{+}$ of lake water (e.g. Holmes et al. 1998). The $\delta^{15} \mathrm{~N}$ values obtained for $\mathrm{NH}_{4}{ }^{+}$for Lake Katanuma water on 15 May were $-4.9 \pm 0.3$ and $-3.6 \pm 0.5 \%$, which were lower than those in Miles Pond $(2.8 \pm 0.6 \%$ ) (Holmes et al. 1998). Lake Katanuma does not have any inflowing streams and is located on a mountain top, suggesting only a limited supply of rainwater (Shikano et al. 2004). It therefore seems likely that the high $\mathrm{NH}_{4}{ }^{+}$concentrations of the lake water are derived from the remineralization of organic matter in the lake. The $\delta^{15} \mathrm{~N}$ value of $\mathrm{NH}_{4}{ }^{+}$for the lake water on 15 May might indicate that re-mineralized $\mathrm{NH}_{4}{ }^{+}$is supplied from the hypolimnion. However, the $\mathrm{NH}_{4}{ }^{+}$in Lake Katanuma water might originally be derived from rainwater, since there is no other water inflow. The $\delta^{15} \mathrm{~N}$ value obtained for $\mathrm{NH}_{4}{ }^{+}$in rainwater range from -10 to $0 \%$ (Kendall 1998). The $\delta^{15} \mathrm{~N}$ values obtained for $\mathrm{NH}_{4}{ }^{+}$for Lake Katanuma water from the surface and at $10 \mathrm{~m}$ depth $(-4.9 \pm 0.3$ and $-3.6 \pm 0.5 \%$ o $)$ equal the medium values for rainwater. Moreover, at a $\mathrm{pH}$ of 2.2, the fractions of $\mathrm{NH}_{4}^{+}$and $\mathrm{NH}_{3}$ gas were $5.4 \times 10^{8}$ and 1, respectively (Emerson et al. 1975). Therefore, the influence of low $\mathrm{pH}$ on the isotope fractionation between $\mathrm{NH}_{4}{ }^{+}$and $\mathrm{NH}_{3}$ gas was negligible in the low $\mathrm{pH}$ water of Lake Katanuma, since $\mathrm{NH}_{4}{ }^{+}$dominated exclusively.

The $\delta^{15} \mathrm{~N}$ value of phytoplankton is determined by physiological characteristics such as growth rates and biomass, as well as the $\delta^{15} \mathrm{~N}$ value and concentration of nitrogenous compounds (Wada 1980, Waser et al. 1998). In the present study, we examined the correlations between the $\delta^{15} \mathrm{~N}$ values obtained for Chlamydomonas acidophila and the concentrations of chl $a$, and environmental factors such as temperature and $\mathrm{NH}_{4}{ }^{+}$and $\mathrm{PO}_{4}{ }^{3-}$ concentrations (Table 1).

The results showed that the $\delta^{15} \mathrm{~N}$ values obtained for Chlamydomonas acidophila were negatively correlated with $\mathrm{NH}_{4}{ }^{+}$concentrations (Pearson's correlation coefficient, $r=-0.637, \mathrm{p}<0.05)$, suggesting that high

Table 1. Correlation (r) between $\delta^{15} \mathrm{~N}$ values obtained for Chlamydomonas acidophila, water temperature (WT), concentrations of $\mathrm{NH}_{4}{ }^{+}, \mathrm{PO}_{4}{ }^{3-}$, and chl $a$ in the surface water between 15 May and 17 July. *Significant $r$-values $(p<0.05$, $\mathrm{n}=14$, Pearson's correlation coefficient)

\begin{tabular}{|c|c|c|c|c|c|}
\hline & $\delta^{15} \mathrm{~N}$ & WT & $\mathrm{NH}_{4}^{+}$ & $\mathrm{PO}_{4}{ }^{3-}$ & Chl a \\
\hline$\delta^{15} \mathrm{~N}$ & & 0.057 & $-0.637^{*}$ & -0.030 & -0.426 \\
\hline WT & & & $-0.605^{*}$ & -0.057 & 0.377 \\
\hline $\mathrm{NH}_{4}{ }^{+}$ & & & & -0.249 & 0.018 \\
\hline $\mathrm{PO}_{4}{ }^{3-}$ & & & & & 0.181 \\
\hline Chl a & & & & & \\
\hline
\end{tabular}


$\mathrm{NH}_{4}{ }^{+}$values result in low particulate $\delta^{15} \mathrm{~N}$ values. The low $\delta^{15} \mathrm{~N}$ values occurred only during periods characterized by high $\mathrm{NH}_{4}{ }^{+}$concentrations (>15 $\mu \mathrm{mol} \mathrm{l} \mathrm{l}^{-1}$ ) (Fig. 2). Thus, our results suggest that the concentration of $\mathrm{NH}_{4}{ }^{+}$is a major determinant of the $\delta^{15} \mathrm{~N}$ value of C. acidophila in Lake Katanuma. The high $\mathrm{NH}_{4}{ }^{+}$values correlate to low particulate $\delta^{15} \mathrm{~N}$ values, owing to isotopic fractionation during ammonium assimilation. In studies using laboratory cultures, similar relationships have been reported. Hoch et al. (1992) reported low $\delta^{15} \mathrm{~N}$ values for phytoplankton at high concentrations of $\mathrm{NH}_{4}{ }^{+}$(50 to $200 \mu \mathrm{mol} \mathrm{l}^{-1}$ ). Pennock et al. (1996) found that the isotopic fractionation of $\mathrm{NH}_{4}{ }^{+}$by phytoplankton varied with ambient $\mathrm{NH}_{4}{ }^{+}$concentration over the range from 5 to $100 \mathrm{mmol} \mathrm{l}^{-1}$, and lower fractionation was observed at lower concentrations of $\mathrm{NH}_{4}{ }^{+}$(5 to $20 \mathrm{\mu mol} \mathrm{l}^{-1}$ ).

In Lake Katanuma, water temperature was negatively correlated with concentrations of $\mathrm{NH}_{4}{ }^{+}(\mathrm{r}=-0.605, \mathrm{p}<$ 0.05) (Table 2). This study was carried out at the beginning of the spring bloom period, and the abundance of Chlamydomonas acidophila increased with increasing water temperature from May to July. Therefore, the negative correlation obtained in this study may show only that the concentration of $\mathrm{NH}_{4}{ }^{+}$tended to decrease with the increasing biomass of $C$. acidophila, because of assimilation by the phytoplankton.

Higher $\delta^{15} \mathrm{~N}$ values obtained for phytoplankton have been reported to be accompanied by higher growth rates and greater biomass (Waser et al. 1998). This did not appear to be the case in Lake Katanuma. Lower

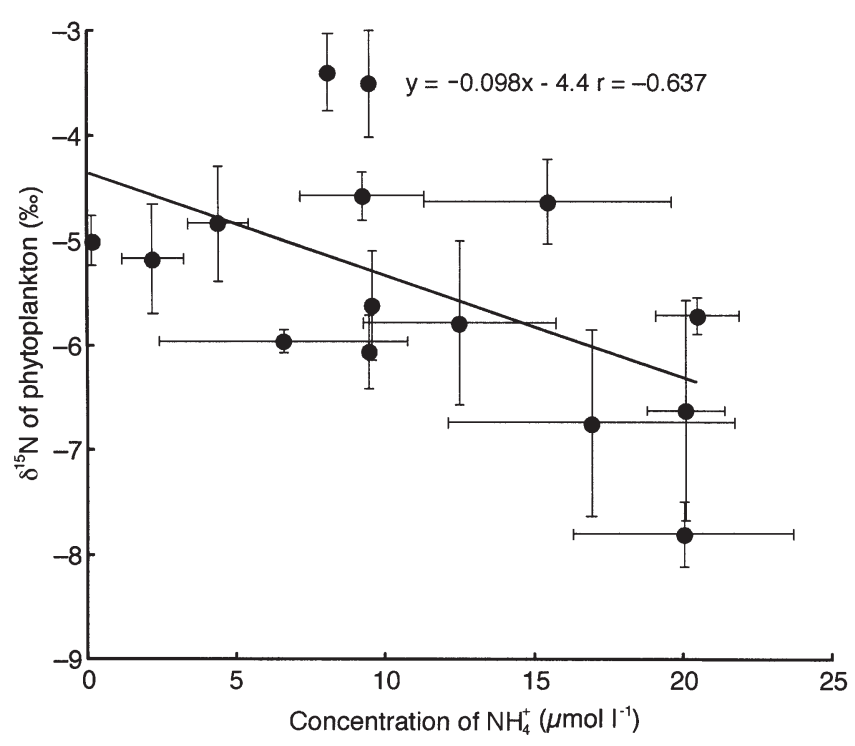

Fig. 2. Chlamydomonas acidophila. Relationship between $\delta^{15} \mathrm{~N}$ values of $C$. acidophila and concentration of $\mathrm{NH}_{4}{ }^{+}$ between 15 May and 17 July. Correlation line gave an r-value of $-0.637(p<0.05, n=14)$. Error bars indicate \pm 1 SD $(n=3)$
Table 2. Chlamydomonas acidophila. Isotope fractionation $(\varepsilon$ : mean $\pm 1 \mathrm{SD}, \mathrm{n}=3$ ) obtained between 15 May and 28 June. Isotope fractionation factor $(\varepsilon)$ was determined using the equation described by Mariotti et al. (1981) and Waser et al. (1998)

\begin{tabular}{|lr|}
\hline Sampling date & \multicolumn{1}{c|}{$\varepsilon(\%)$} \\
\hline 15 May & $1.2 \pm 0.1$ \\
16 May & $0.3 \pm 0.2$ \\
17 May & $1.1 \pm 0.4$ \\
18 May & $0.2 \pm 0.3$ \\
19 May & $-1.0 \pm 0.5$ \\
20 May & $0.5 \pm 0.4$ \\
22 May & $1.9 \pm 0.2$ \\
25 May 9 May & $2.1 \pm 0.4$ \\
5 Jun & $2.8 \pm 0.8$ \\
19 Jun 8 Jun & $3.5 \pm 0.9$ \\
& $1.2 \pm 0.5$ \\
\end{tabular}

$\delta^{15} \mathrm{~N}$ values of the phytoplankton were observed following a rapid increase in chl a concentration from 21 to 29 May (Fig. 1A), and there was no significant correlation between the $\delta^{15} \mathrm{~N}$ value of the phytoplankton and concentrations of chl $a$, which is indicative of the biomass of Chlamydomonas acidophila (Table 1).

The isotope fractionation factor $(\varepsilon)$ was determined, as described by Mariotti et al. (1981), as an indicator of ${ }^{15} \mathrm{~N}$ enrichment. To calculate $\varepsilon$, the $\delta^{15} \mathrm{~N}$ values of $\mathrm{NH}_{4}{ }^{+}$ were necessary, and were calculated using the following isotope mixing model equation, since the $\mathrm{NH}_{4}{ }^{+}$of surface water was derived from the hypolimnion:

on 15 May:

$$
\delta^{15} \mathrm{~N}_{\text {DIN }}=\delta^{15} \mathrm{~N}_{\text {DIN }} \text { (initial at } 15 \text { May) }
$$

from 16 May to 5 June:

$\delta^{15} \mathrm{~N}_{\text {DIN }}$ (sampling day) $=\left(1-f_{\mathrm{N}}\right) \delta^{15} \mathrm{~N}_{\text {DIN }}(1 \mathrm{~d}$ before sampling day) $+f_{\mathrm{N}} \delta^{15} \mathrm{~N}_{\text {DIN }}$ (hypolimnion), and

$$
\begin{gathered}
f_{\mathrm{N}}=\left[\mathrm{NH}_{4}{ }^{+}(\text {sampling day })-\mathrm{NH}_{4}{ }^{+}(1 \mathrm{~d} \text { before }\right. \\
\text { sampling })] \times\left[\mathrm{NH}_{4}{ }^{+}(\text {sampling day })\right]^{-1}
\end{gathered}
$$

where $\delta^{15} \mathrm{~N}_{\text {DIN }}$ (initial at 15 May) and $\delta^{15} \mathrm{~N}_{\text {DIN }}$ (hypolimnion) were assumed to be -4.9 and $-3.6 \%$, respectively, since the DIN in Lake Katanuma is composed almost entirely of $\mathrm{NH}_{4}{ }^{+}$. Since $f_{\mathrm{N}} \geq 0$, DIN was calculated for 16, 17, 20, 21, 25 May, and 5 June, while on the other sampling days $\left(f_{\mathrm{N}}<0\right) \delta^{15} \mathrm{~N}_{\text {DIN }}$ was assumed to have the same values as those of the previous samples, since the $\mathrm{NH}_{4}{ }^{+}$supply from the hypolimnion may be negligible.

Assuming that the initial $\delta^{15} \mathrm{~N}$ value of $\mathrm{NH}_{4}{ }^{+}$was $-4.9 \%$, the isotope fractionation factor $(\varepsilon)$ was calculated for the sampling period from 16 May to 18 May and from 22 May to 28 June using the model for closed-system conditions described by Mariotti et al. (1981) and Waser et al. (1998) as follows: 
on 15 May:

$$
\varepsilon=\delta^{15} \mathrm{~N}_{\text {DIN }} \text { (initial at } 15 \text { May) }-\delta^{15} \mathrm{~N}_{\text {phytoplankton }}
$$

for the periods from 16 May to 18 May and from 22 May to 28 June:

$$
\varepsilon=\left(\delta^{15} \mathrm{~N}_{\text {DIN }}-\delta^{15} \mathrm{~N}_{\text {phytoplankton }}\right) /\left[-f(1-f)^{-1}\right] \ln f
$$

$f=\mathrm{NH}_{4}{ }^{+}$(sampling day) $\times\left[\mathrm{NH}_{4}{ }^{+}\right.$(initial at $\left.\left.15 \mathrm{May}\right)\right]^{-1}$ where $\delta^{15} \mathrm{~N}_{\text {phytoplankton }}$ and $\delta^{15} \mathrm{~N}_{\text {DIN }}$ indicate $\delta^{15} \mathrm{~N}$ values of phytoplankton and $\mathrm{NH}_{4}{ }^{+}$, respectively. $f$ means the fraction of unreacted $\mathrm{NH}_{4}{ }^{+}$on sampling days during our study. On 17 July, the $\varepsilon$ values of Chlamydomonas acidophila may not be accurate, since $\mathrm{NH}_{4}{ }^{+}$concentrations were extremely low and below detection limits; thus unreacted $\mathrm{NH}_{4}{ }^{+}$could not be calculated accurately.

For the period from 19 to 21 May, $\varepsilon$ was calculated using the model for open-system conditions, with the following equation (Mariotti et al. 1981), since partial mixing of lake water was observed during 19 to 21 May, the surface water system for phytoplankton was not closed, and the $\mathrm{NH}_{4}^{+}$concentration increased significantly:

$$
\varepsilon=\delta^{15} \mathrm{~N}_{\text {phytoplankton }}-\delta^{15} \mathrm{~N}_{\text {DIN }} \text { (sampling day) }
$$

The isotope fractionations $(\varepsilon)$ obtained for Chlamydomonas acidophila ranged from -1.0 to $3.9 \%$ between 15 May and 28 June (Table 2). These values are lower than those reported for many other $\mathrm{NH}_{4}{ }^{+}$-based primary producers in other water bodies, which usually range from 6.5 to 9.1\%o (Cifuentes et al. 1989, Montoya et al. 1991). The low values obtained for $C$. acidophila in this study indicate low ${ }^{15} \mathrm{~N}$-depletion in phytoplankton in Lake Katanuma. Research using laboratory cultures has shown isotope fractionation by phytoplankton to decrease during nutrient starvation (Hoch et al. 1992, Waser et al. 1998, 1999). Waser et al. (1998) suggested that isotope fractionation by phytoplankton decreases with decreasing concentrations of $\mathrm{NH}_{4}{ }^{+}$. The concentrations of $\mathrm{NH}_{4}{ }^{+}$in Lake Katanuma were $<20 \mathrm{mmol} \mathrm{l}^{-1}$, much lower than those used in laboratory culture experiments (23 to $190 \mu \mathrm{mol} \mathrm{l^{-1 }}$; Hoch et al. 1992, Waser et al. 1998, 1999). Therefore, the low concentration of $\mathrm{NH}_{4}{ }^{+}$in Lake Katanuma may be the reason for the low isotope fractionation values.

Acknowledgements. We would like to thank Dr. K. Itoh of the Department of Agriculture, Tohoku University, for her permission to use the stable isotope analytical facilities in her laboratory. We are grateful to Dr. S. Hino of the Department of Materials and Biological Chemistry, Faculty of Science, Yamagata University, for technical advice on the measurement of nutrient concentrations. We are grateful to Dr. K. Koba of the Interdisciplinary Graduate School of Science and Engineering, Tokyo Institute of Technology, for technical advice on the nitrogen isotope measurement of ammonium. We also thank Mr. T. Toya and Mr. E. Nobata of the Graduate School of Sciences, Tohoku University, for advice on the use of stable isotopes and for help with sampling.

\section{LITERATURE CITED}

Cifuentes LA, Fogel ML, Pennock JR, Sharp JH (1989) Biogeochemical factors that influence the stable nitrogen isotope ratio of dissolved ammonium in the Delaware Estuary. Geochim Cosmochim Acta 53:2713-2721

Doi H, Kikuchi E, Shikano S (2001) Carbon and nitrogen stable isotope ratios analysis of food sources for Chironomus acerbiphilus larvae (Diptera Chironomidae) in strongly acidic Lake Katanuma. Radioisotopes 50:601-611

Doi H, Kikuchi E, Hino S, Itoh T, Takagi S, Shikano S (2003a) Isotopic $\left(\delta^{13} \mathrm{C}\right)$ evidence for autochthonous origin of sediment organic matter in small, acidic Lake Katanuma, Japan. Mar Freshw Res 54:253-257

Doi H, Kikuchi E, Hino S, Itoh T, Takagi S, Shikano S (2003b) Seasonal dynamics of carbon stable isotope ratios of particulate organic matter and benthic diatoms in strongly acidic Lake Katanuma. Aquat Microb Ecol 33:87-94

Emerson KR, Russo C, Lund RE, Thurston RV (1975) Aqueous ammonia equilibrium calculations: effect of $\mathrm{pH}$ and temperature. J Fish Res Board Can 32:2379-2383

Hecky RE, Campbell P, Hendzel LL (1993) The stoichiometry of carbon, nitrogen, and phosphorus in particulate matter of lakes and oceans. Limonol Oceanogr 39:709-724

Hoch MP, Fogel ML, Kirchman DL (1992) Isotope fractionation associated with ammonium uptake by a marine bacterium. Limnol Oceanogr 37:1447-1459

Holmes RM, McClelland JW, Sigman DM, Fry B, Peterson BJ (1998) Measuring ${ }^{15} \mathrm{~N}-\mathrm{NH}_{4}{ }^{+}$in marine, estuarine and fresh waters: an adaptation of the ammonium diffusion method for samples with low ammonium concentrations. Mar Chem 60:235-243

Kendall C (1998) Tracing nitrogen sources and cycling in catchments. In: Kendall C, McDonnell JJ (eds) Isotope tracers in catchment hydrology. Elsevier, Amsterdam, p 519-576

Mariotti A, Germon JC, Hubert P, Kaiser P, Letolle R, Tardieux A, Tardieux P (1981) Experimental determination of nitrogen kinetic isotope fractionation: some principles; illustration for the denitrification and nitrification processes. Plant Soil 62:413-430

Meyers PA (1994) Preservation of elemental and isotopic source identification of sedimentary organic matter. Chem Geol 144:289-302

Minagawa M, Wada E (1986) Nitrogen isotope ratios of red tide organisms in the East China Sea: a characterization of biological nitrogen fixation. Mar Chem 19:553-567

Mitamura O, Saijo Y (1986) Urea metabolism and its significance in the nitrogen cycle in the euphotic layer of Lake Biwa Japan. I. In situ measurement of nitrogen assimilation and urea decomposition. Arch Hydrobiol 107:23-52

Montoya JP, Horrigan SG, McCarthy JJ (1991) Rapid, storminduced changes in the natural abundance of ${ }^{15} \mathrm{~N}$ in a planktonic ecosystem, Chesapeake Bay, USA. Geochim Cosmochim Acta 55:3627-3638

Pennock JR, Velinsky DJ, Ludlam JM, Sharp JH, Fogel ML (1996) Isotopic fractionation of ammonium and nitrate during uptake by Skeletonema costatum: implications of $\delta^{15} \mathrm{~N}$ dynamics under bloom conditions. Limnol Oceanogr 41:451-459

Redfield AC, Ketchum BH, Richards FA (1963) The influence of organisms on the composition of seawater. In: Hill MN (ed) The sea, Vol 2. John Wiley \& Sons, New York, p 26-77

Scheiner D (1976) Determination of ammonia Kjeldhal nitrogen by indophenol method. Water Res 10:31-36

Shikano S, Kikuchi E, Takagi S, Doi H (2004) Volcanic heat flux and shortterm holomixis during the summer stratification period in a crater lake. Limnol Oceanogr (in press) 
Strickland JDH, Parsons TR (1972) A practical handbook of seawater analysis, 2nd edn. Bulletin of the Fisheries Research Board of Canada, Ottawa

Wada E (1980) Nitrogen isotope fractionation and its significance in biogeochemical processes occurring in marine environments. In: Goldgerg ED, Horibe Y, Saruhashi K (eds) Isotope marine chemistry. Uchida-Rokakuho, Tokyo, p 375-398

Wada E, Hattori A (1976) Natural abundance of ${ }^{15} \mathrm{~N}$ in particulate organic matter in the North Pacific Ocean. Geochim Cosmochim Acta 40:249-251

Editorial responsibility: Paul Harrison, Kowloon, Hong Kong
Waser NA, Yin K, Yu DZ, Ada KT, Harrison PJ, Turpin DH, Calvert SE (1998) Nitrogen isotope fractionation during nitrate, ammonium and urea uptake by marine diatoms and coccolithophores under various conditions of $\mathrm{N}$ availability. Mar Ecol Prog Ser 169:29-41

Waser NA, Yu DZ, Yin K, Nielsen B, Harrison PJ, Calvert SE (1999) Nitrogen isotopic fractionation during a simulated diatom spring bloom: importance of N-starvation in controlling fractionation. Mar Ecol Prog Ser 179:291-296

Wetzel RG (2001) Limnology lake and river ecosystems, 3rd edn. Academic Press, San Diego, p 214-216

Submitted: July 23, 2003; Accepted: June 16, 2004

Proofs received from author(s): July 28, 2004 